Original Research Paper

\title{
Area-Wide Control Program of Chinese Citrus Fly Bactrocera minax (Enderlein) in Sindhuli, Nepal
}

\author{
${ }^{1}$ Debraj Adhikari*, ${ }^{1}$ Resham Bahadur Thapa, ${ }^{2}$ Samudra Lal Joshi, ${ }^{3}$ Xing Hui Liang and ${ }^{3}$ Jason Jinping Du \\ ${ }^{1}$ Agriculture and Forestry University, Nepal \\ ${ }^{2}$ Nepal Agricultural Research Council, Nepal \\ ${ }^{3}$ Beijing Ecoman Biotech Co. Ltd., China
}

\author{
Article history \\ Received: 30-09-2019 \\ Revised: 13-01-2020 \\ Accepted: 18-01-2020 \\ Corresponding Author: \\ Debraj Adhikari \\ Agriculture and Forestry \\ University, Nepal \\ Email: adhikari.debraj@gmail.com
}

\section{Introduction}

Citrus fruits are grown commercially in about 140 countries in the world (NRC, 2010). Citrus is an important fruit commodity in the mid-hill of Nepal. Mandarin (Citrus reticulata Blanco) holds the first position in terms of area and production followed by sweet orange (Citrus sinensis (L.) Osbeck) in Nepal (Amgai et al., 2016). Citrus fruits are generally consumed as fresh fruit as well and extraction of juice and further processing (Adhikari and Rayamajhi, 2012). Sindhuli and Ramechhap are the two major sweet orange growing districts in Nepal. The sweet orange variety Orange

\begin{abstract}
Citrus plays a significant role in providing nutrition to people and generating income for the citrus farmers in Nepal. Among various biotic problems in citriculture, Chinese Citrus Fly (CCF), Bactrocera minax (Enderlein) (Diptera: Tephritidae) has become a major threat to the production of the tight skin citrus fruits, viz. sweet orange, lemon and ine in recent years. This invasive species originated in China and seems (India) entered into north-eastern Nepal through Bhutan and Sikkim CCF has shown a yearly increasing pattern since 2014 in the central hilly citrus orchards in the districts of Sindhuli and Ramechhap. Sindhuli district holds the first position in terms of sweet orange acreage and its production in Nepal. Conventional pest control measures including pesticide cover spray seemed to have resulted in limited effect in controlling CCF. Thus, as a pilot program, an Area-Wide Control Program (AWCP) of this pest was conducted in 40 ha of sweet orange orchards at Golanjor Rural Municipality-4, Tinkanya in Sindhuli, Nepal to minimize the fruit damages by maggots of $B$. minax. AWCP focused on the life cycle based management strategy of this pest, targeting the female adult fly population. Formulated protein bait (Great Fruit Fly Bait) containing $25 \%$ protein hydrolysate and $0.1 \%$ Abamectin was used as spot application underside of the 0.5 to $1 \mathrm{~m}^{2}$ leaf for 10 times at a weekly interval from May to July 2018 as per the protocol developed by Ecoman Biotech, China. The result revealed that the leaf underside spot treatment with the protein bait was highly efficient to minimize the sweet orange fruit losses from 56.7 to $10.9 \%$. Coordination among stakeholders along with sound technical aspect and managerial function seemed essential for
\end{abstract}

Keywords: AWCP, Bactrocera minax, Citrus, Nepal, Protein Bait, Sweet

produced in Sindhuli is called JUNAR in Nepal has its own history of origin in the Ratanchura and Nakajoli villages there. Thus, the sweet orange cultivation in Sindhuli is vital for the income generation and for the name and fame of the district. The sweet orange produced in Sindhuli is popularly known all over the country as "SINDHULIKO JUNAR" means sweet orange from Sindhuli.

Nowadays, sweet orange production has several problems such as lack of irrigation facility in the orchard, unavailability of quality planting materials, poor adaptation of recommended orchard husbandry measures, incidence of 
insects and diseases, post-harvest losses and marketing problems, etc. Fruit flies (Diptera: Tephritidae) are devastating pests of fruit and fruit vegetables having global importance (Aluja et al., 2012; Aluja and Mangan, 2008; Adhikari et al., 2016). Fruit flies (Diptera: Tephritidae) are one of the most destructive and well-known pests of fruits and vegetables around the globe (USDA, 2009). Fruit loss due to the infestation of Chinese Citrus Fly (CCF), Bactrocera minax (Enderlein) has become a devastating issue since 2014 (Adhikari and Joshi, 2018; Adhikari et al., 2018) that originated in China, seems to have entered into the north-eastern Nepal region through Bhutan and Sikkim (India) (Joshi, 2019). The reasons behind the failure of widespread success in pest control are lack of thorough understanding of pest biology, population dynamics, agroecosystem and climatic patterns (Stenseth et al., 2002; Parmesan and Yohe, 2003).

The concept of Area-Wide Control Program (AWCP) involved developing and integrating biologically-based pest control technologies into a comprehensive management package that would be economically viable, environmentally sensitive and sustainable. Jessup et al. (2007) highlighted the achievement of AW-IPM programs that were depended on the proper monitoring of fruit flies, correct and rapid response to incursions and active participation by all growers and other stakeholders' area under the AW-IPM program. Multiagency collaboration and transfer of area-wide IPM approaches to farmers for suppression of fruit flies are also important component of the AW-IPM program (Vargas et al., 2007). The technologies included in the AWCP were field sanitation, protein bait sprays and/or traps, etc. Many of these technologies along with the Great fruit fly bait (Protein hydrolysate 25+0.1\% Abamectin) were developed by Ecoman Biotech in China and were transferred to the citrus orchards in Sindhuli. AWCP was implemented to manage CCF in Sindhuli, Nepal with an objective of suppression of fly populations and fruit damage minimization. This paper highlights on the result obtained from the said technology backed AWCP against CCF in the Sindhuli orchards of sweet orange.

\section{Methodology}

The AWCP of Bactrocera minax (Enderlein) was carried out in Golanjor Rural Municipality -4, Tinkanya covering 40 ha of sweet orange orchards in 2018. This organized program was the joint efforts of Junar Superzone (Prime Minister Agriculture Modernization Project, Program Implementation Unit), Sindhuli, Karma Chemical Company Pvt. Ltd. (Kathmandu), Ecoman Biotech (China) and the sweet orange growers of Tinkanya, Sindhuli, Nepal. The technical protocol along with the protein bait (Great fruit fly bait) of AWCP was provided by Ecoman Biotech, China. The activities performed to accomplish the $B$. minax AWCP could be divided into two aspects, viz. managerial and technical (Fig. 1).

Managerial aspect included consultation with stakeholders in the district, local and national levels, clustering of selected sweet orange orchards for proper spray plan, orientation (training and education) to spray persons and orchard owners before spray program and monitoring and feedback during and after spray. An interaction program with concerned technical and managerial personnel of Junar Superzone was organized at Khaniyakharka, Sindhuli and a workshop was organized by Junar Superzone, Sindhuli at Sindhulimadi to share the managerial and technical aspects of AWCP. Moreover, a national workshop on $B$. minax AWCP was organized at Kathmandu to share and get feedback on the ongoing activities from national and international experts.

The technical aspect of this program- assessment of fruit loss due to the maggots of $B$. minax in each selected orchards, monitoring of adult emergence using nets in the ground under the sweet orange trees and using protein bait traps were accomplished accordingly. The major feature of the AWCP protocol is to attract the newly emerged adult flies in the protein bait as a lethal dinner. The protein bait solution was prepared out of Great fruit fly bait 1 part in 2 parts of water and $50 \mathrm{ml}$ of this prepared solution was sprayed in an area of 0.5 to 1 $\mathrm{m}^{2}$ underside of the leaves of one in three productive sweet orange trees. The spray was performed in all citrus orchard clusters on the same day. The spray was repeated ten times in each cluster at an interval of 7 days from May 13 to July 14, 2018, as presented in Table 1.

Table 1: Protein bait spray schedule

\begin{tabular}{|c|c|c|c|}
\hline $\mathrm{SN}$ & Spray action & Spray date & Protein bait + Water $=$ Spray solution \\
\hline 1 & First spray & 13 May 2018 & Protein bait 97.34 lit + Water 194.72 lit $=194.82$ lit \\
\hline 2 & Second spray & 19 May 2018 & Protein bait 97.34 lit + Water 194.72 lit $=194.82$ lit \\
\hline 3 & Third spray & 26 May 2018 & Protein bait 97.34 lit + Water 194.72 lit $=194.82$ lit \\
\hline 4 & Fourth spray & 2 June 2018 & Protein bait 97.34 lit + Water 194.72 lit $=194.82$ lit \\
\hline 5 & Fifth spray & 9 June 2018 & Protein bait 97.34 lit + Water 194.72 lit $=194.82$ lit \\
\hline 6 & Sixth spray & 16 June 2018 & Protein bait 97.34 lit + Water $194.72 \mathrm{lit}=194.82 \mathrm{lit}$ \\
\hline 7 & Seventh spray & 23 June 2018 & Protein bait 97.34 lit + Water 194.72 lit $=194.82$ lit \\
\hline 8 & Eighth spray & 30 June 2018 & Protein bait 97.34 lit + Water 194.72 lit $=194.82$ lit \\
\hline 9 & Ninth spray & 7 July 2018 & Protein bait $97.34 \mathrm{lit}+$ Water $194.72 \mathrm{lit}=194.82 \mathrm{lit}$ \\
\hline 10 & Tenth spray & 14 July 2018 & Protein bait 97.34 lit + Water 194.72 lit $=194.82$ lit \\
\hline
\end{tabular}




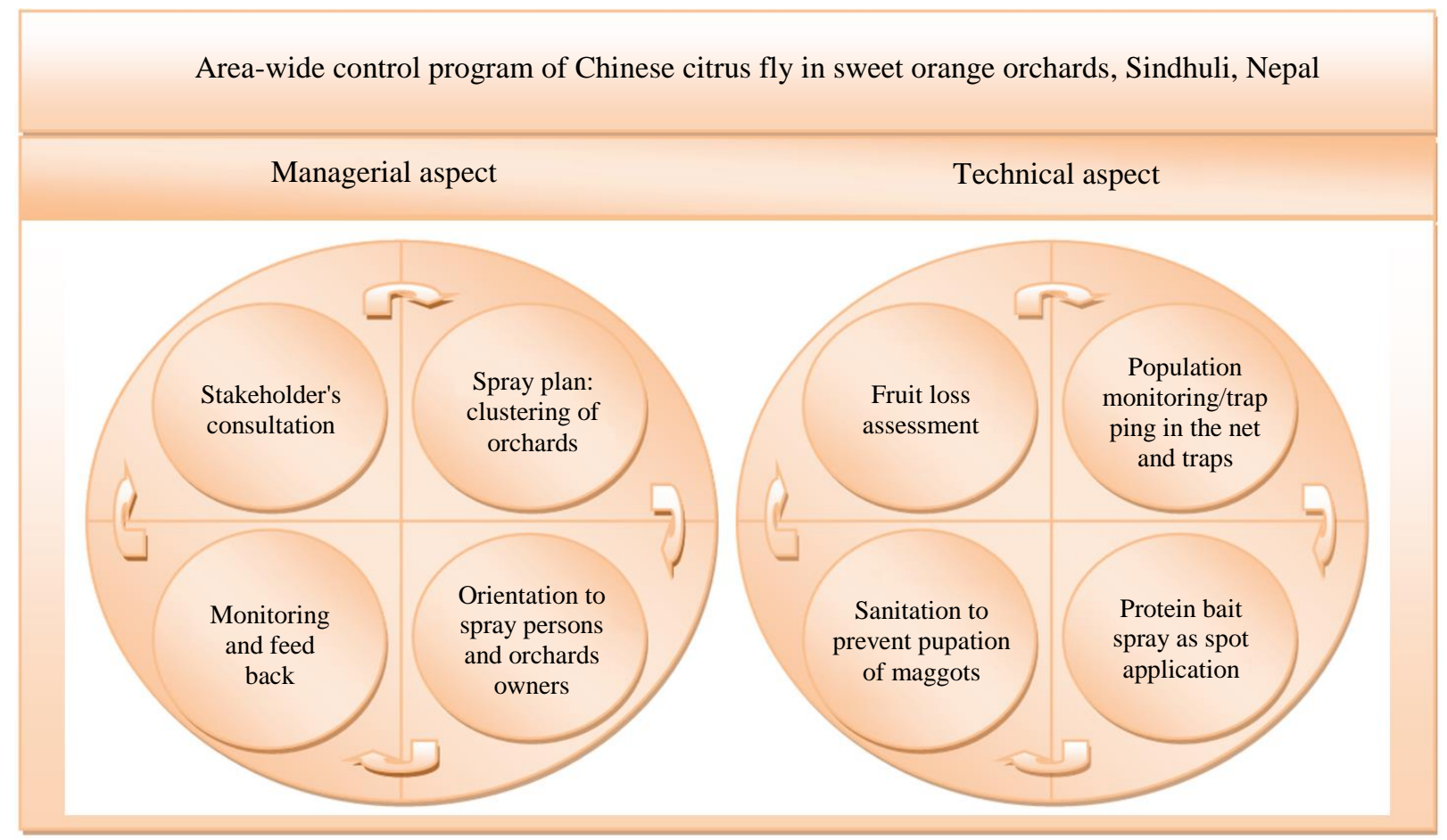

Fig. 1: Managerial and technical aspects of AWCP of CCF, Bactrocera minax (Enderlein) in Sindhuli, Nepal

Data on clusters of AWCP, assessment of CCF incurred fruit damages in individual orchards in 2017 , AWCP-2018 and assessment of CCF incurred fruit damages in 2018 from selected orchards were collected and analyzed using MS Excel and R-Studio statistical package.

\section{Results and Discussion}

\section{Details on Clusters of AWCP}

GPS location (longitude, latitude and elevation) of each site is shown in Table 2 and Fig. 2. The total orchard owners were recorded highest, 82, in Majhkhuvinde followed by Mathlo Aalegaun (43) and Ranikhola (39). The total orchard owners involved in the AWCP were 231. The area under sweet orange cultivation, number of productive sweet orange trees is illustrated in Table 2. The largest cluster was Majhkuvinde followed by Mathlo Aalegaun and Tallo Aalegaun. Similarly, the number of spots sprayed once and the numbers of spray persons involved in the AWCP is presented in Table 2. In Australia, the pest free area of fruit fly has been achieved and maintained by clustering different areas using Area-Wide Integrated Pest Management (AW-IPM) principles. Whereas, some parts of Australia have endemic populations of pest species of fruit flies (Jessup et al., 2005).
Assessment of Fruit Damage Due to CCF, B. minax in 2017

The average fruit loss due to $\mathrm{CCF}, B$. minax was reported $56.7 \%$ in the year 2017 . Highest fruit damage was recorded in Ranikhola $(73.25 \%)$ followed by Tamaure (71.5\%), Majhkuvinde (52.6\%), Mathlo Aalegaun (45.7\%) and Tallo Aalegaun (40.5\%), respectively.

The fruit loss due to the maggots of CCF, B. minax was reported increasing in trend as compared to the previous year in a tune of 17 to $30 \% 2014$ to 2017 in the Sindhuli district (DADO Sindhuli, 2018).

\section{AWCP and Assessment of Damaged Fruits Due to $C C F, B$. minax in 2018}

Assessment of the effectiveness of AWCP was conducted by assessing the damage of fruits due to the $B$. minax maggots and other causes. The result revealed that the deployment of AWCP was highly efficient to minimize the $B$. minax incurred sweet orange fruit losses by $45.8 \%(56.7 \%$ in 2017 to $10.90 \%$ in 2018) that the difference is highly significant (Table 3 and Fig. 4). Fruit loss recovery in each cluster after AWCP in 2018 is obviously seen in the light of losses obtained in different clusters before AWCP deployment (Fig. 3). 
The fruit loss is directly related to production depletion and income minimization to the growers. Moreover, other factors other than B. minax like water stress, nutritional disorders, bug damage, etc. also found responsible to deplete fruit yield to $6 \%$ as observed in 2018 by the growers (Fig. 5). Thus, in this context, $B$. minax solely should not be incriminated for the fruit damage in the orchards.

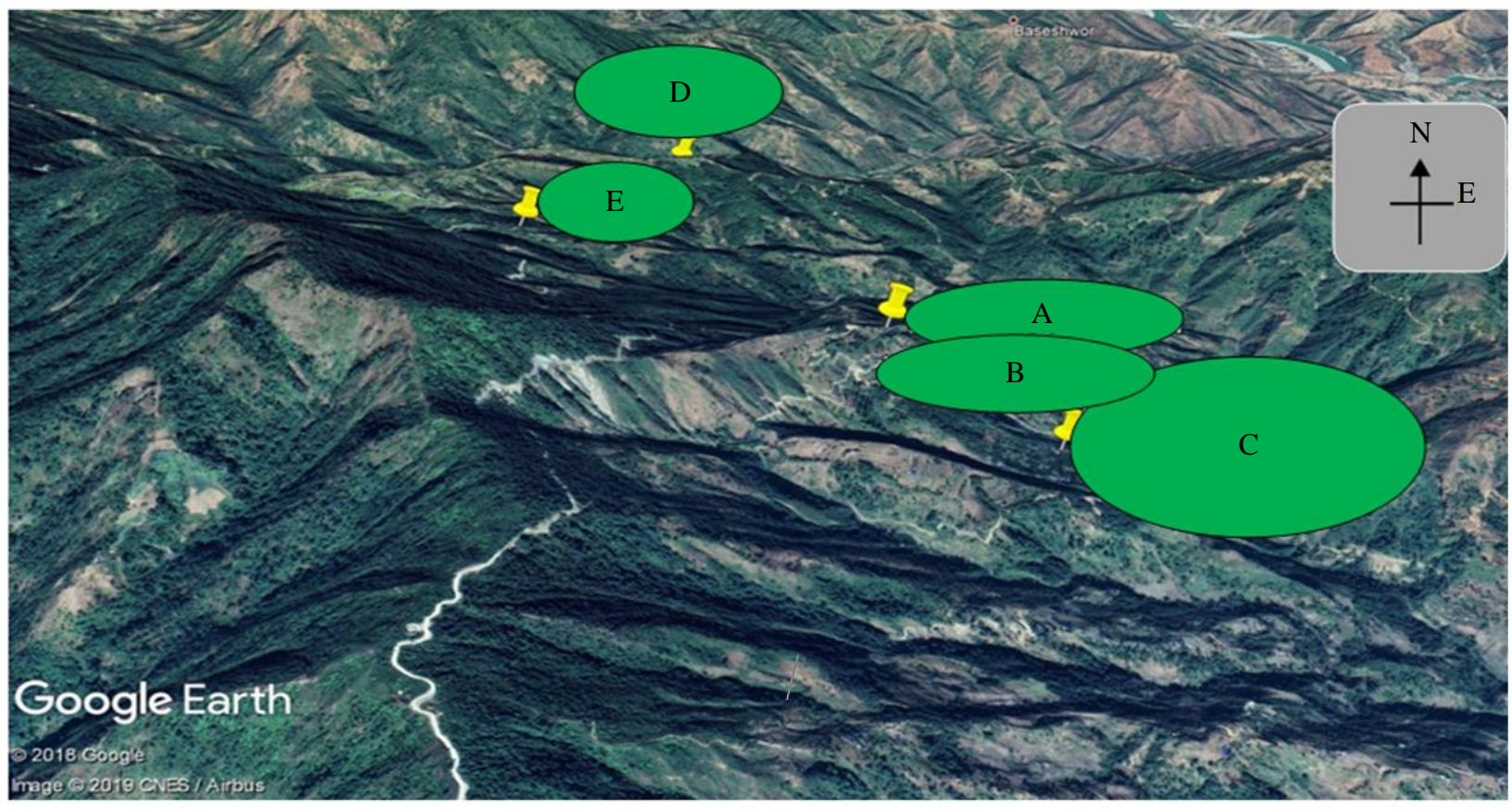

Fig. 2: Clusters of AWCP of CCF, B. minax at Tinkanya, Sindhuli, Nepal

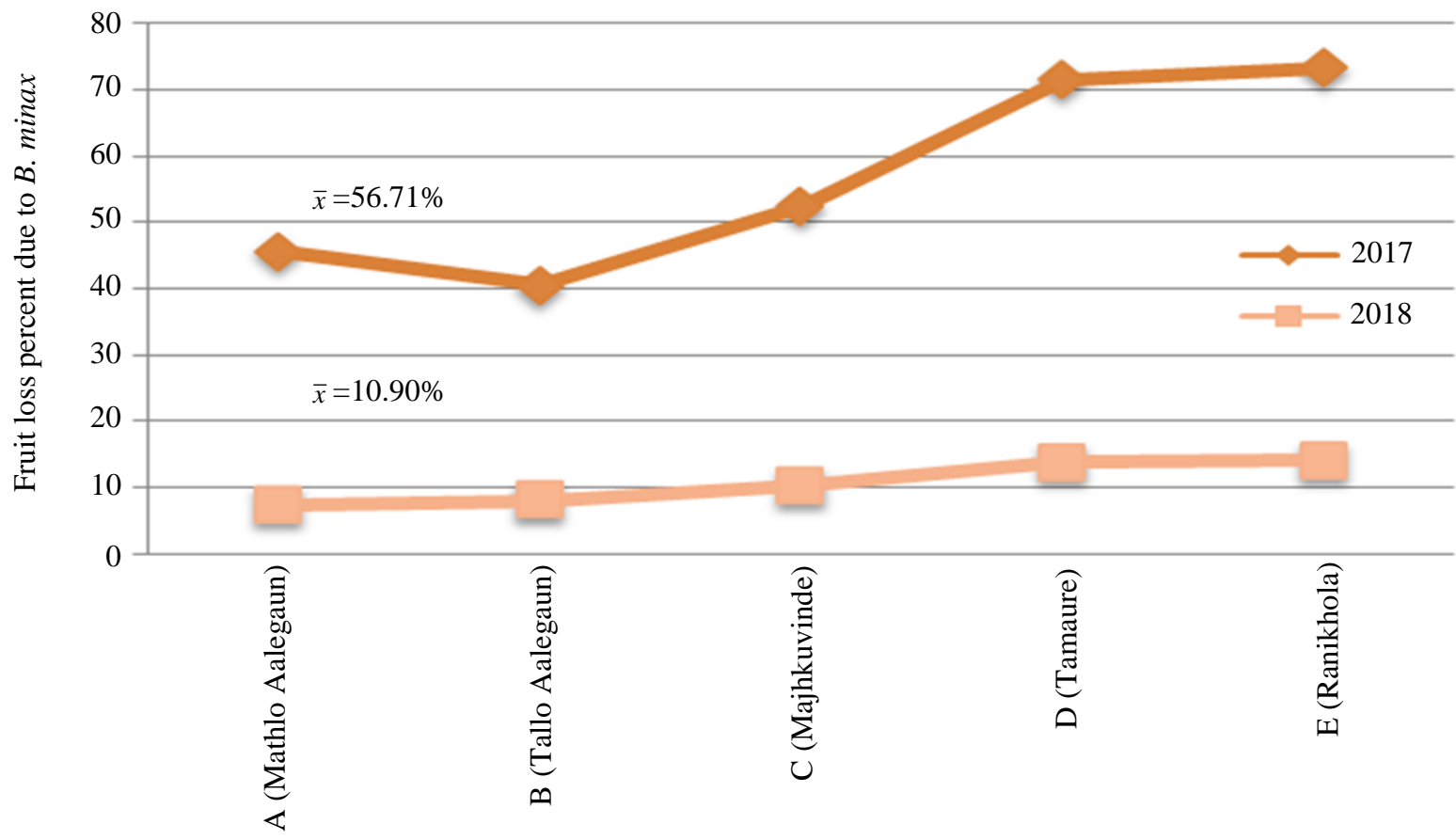

Clusters of AWCP

Fig. 3: Sweet orange fruit damage due to CCF, B. minax before and after AWCP 
Debraj Adhikari et al. / American Journal of Agricultural and Biological Sciences 2020, Volume 15: 1.7

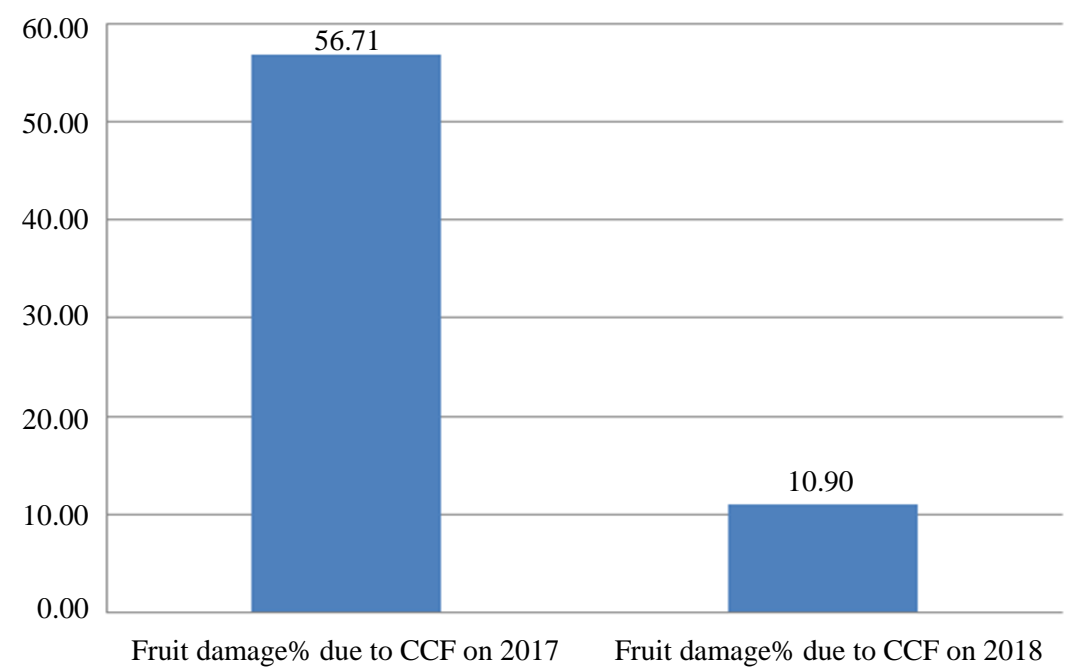

Fig. 4: Comparision of fruit damage due to B. minax before and after AWCP

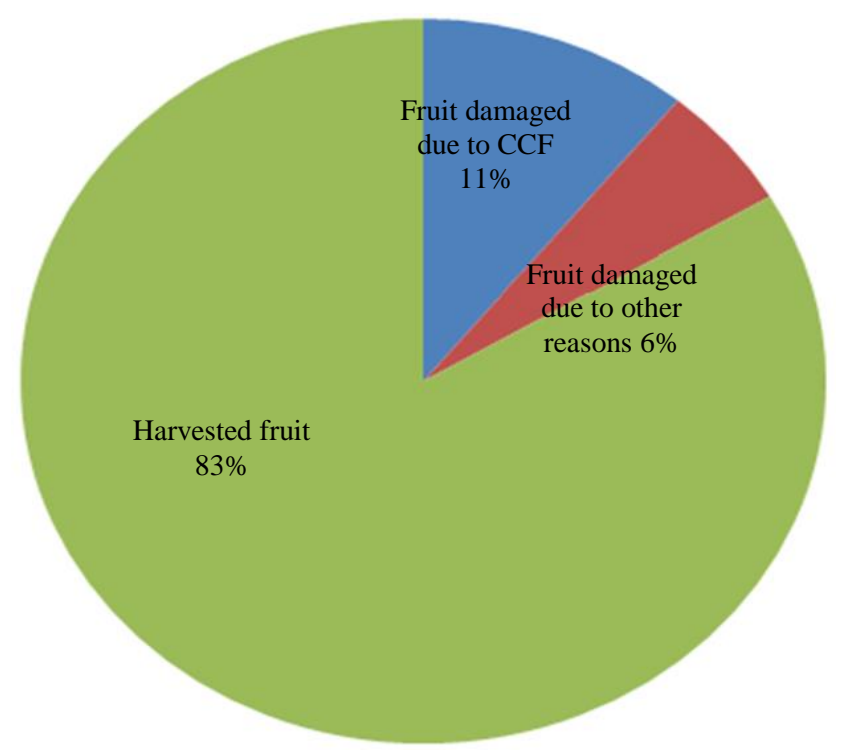

Fig. 5: Sweet orange fruit damage due to different causes in 2018

Table 2: Detail of clusters of AWCP (Longitude, latitude, elevation, total orchard owners, number of productive sweet orange trees and percentage of fruit loss due to Table 2:
CCF, B. minax in 2017, number of spots to be sprayed once and spray person involved in AWCP)

\begin{tabular}{|c|c|c|c|c|c|c|c|c|}
\hline SN & Cluster & $\begin{array}{l}\text { Clusters of AWCP } \\
\text { (Villages/ Settlements) }\end{array}$ & $\begin{array}{l}\text { GPS location and } \\
\text { elevation (masl) }\end{array}$ & $\begin{array}{l}\text { Total orchard } \\
\text { owners }\end{array}$ & $\begin{array}{l}\text { Number of } \\
\text { productive trees }\end{array}$ & $\begin{array}{l}\text { Fruit loss }(\%) \text { due } \\
\text { to } B . \text { minax in } 2017\end{array}$ & $\begin{array}{l}\text { Number of spots } \\
\text { sprayed once }\end{array}$ & $\begin{array}{l}\text { Number of spray } \\
\text { person involved }\end{array}$ \\
\hline 1 & A & Mathlo Aalegaun & $\begin{array}{l}\text { N 27013.670' } \\
\text { E } 086003.507^{\prime} \\
1240\end{array}$ & 43 & 3300 & 45.72 & 1287 & 2 \\
\hline 2 & B & Tallo Aalegaun & $\begin{array}{l}\text { N 27014.124' } \\
\text { E 086003.592' } \\
1092\end{array}$ & 29 & 3860 & 40.54 & 1100 & 2 \\
\hline 3 & $\mathrm{C}$ & $\begin{array}{l}\text { Majhkuvinde, } \\
\text { Thakurigaun, } \\
\text { Dandatole }\end{array}$ & $\begin{array}{l}\text { N 27013.412' } \\
\text { E 086003.729' } \\
1091\end{array}$ & 82 & 6833 & 52.55 & 2278 & 4 \\
\hline 4 & $\mathrm{D}$ & $\begin{array}{l}\text { Tamaure, } \\
\text { Kirate, } \\
\text { Simle }\end{array}$ & $\begin{array}{l}\text { N 27013.532' } \\
\text { E 086003.642' } \\
1010\end{array}$ & 38 & 2010 & 71.50 & 670 & 1 \\
\hline 5 & $\mathrm{E}$ & Ranikhola & $\begin{array}{l}\text { N 27013.763' } \\
\text { E } 086002.448^{\prime} \\
1435\end{array}$ & 39 & 1175 & 73.25 & 392 & 1 \\
\hline \multicolumn{4}{|c|}{ Total/average } & 231 & 17178 & 56.71 & 5727 & 10 \\
\hline
\end{tabular}


Table 3: Assessment of fruit damage due to CCF, B. minax before and after AWCP

\begin{tabular}{llllll}
\hline Assessment of AWCP & Mean fruit damage $(\%)$ & sd & df & t-value & p-value \\
\hline Before AWCP & 56.71 & 33.77 & 27 & 8.2012 & $8.312 \mathrm{e}-09$ \\
After AWCP & 10.90 & 10.97 & & & \\
\hline
\end{tabular}

Table 4: Marketable sweet orange production and total income before and after AWCP

\begin{tabular}{lcccc}
\hline Cluster & $\begin{array}{c}\text { Marketable sweet orange } \\
\text { production in 2017 (mt.) }\end{array}$ & $\begin{array}{l}\text { Marketable sweet orange } \\
\text { production in 2018 (mt.) }\end{array}$ & $\begin{array}{l}\text { Total income in 2017 before } \\
\text { AWCP (in thousands) }\end{array}$ & $\begin{array}{l}\text { Total income in 2018 after } \\
\text { AWCP (in thousands) }\end{array}$ \\
\hline A & 98.52 & 167.80 & 4433 & 7551 \\
B & 126.23 & 194.79 & 5681 & 8765 \\
C & 178.32 & 336.54 & 8025 & 15144 \\
D & 31.51 & 95.05 & 1418 & 4277 \\
E & 17.29 & 55.42 & 778 & 2494 \\
Total & 409.00 & 841.77 & 18405 & 37880 \\
\hline
\end{tabular}

Integrated Pest Management (IPM) is one method to achieve sustainable agricultural production with less damage to the environment (Kogan and Bajwa, 1999). Area-wide management of fruit fly in orange orchards in Karo district of North Sumatra, Indonesia over a period of 2 years (2013 to 2014) was implemented by Ministry of Agriculture of Indonesia, together with GIZ and other related stakeholders that suppressed the population of fruit fly and saved fruit production by about 50\% (ASEAN SAS, 2015). In China, area-wide pest management is not commonly adopted by all growers. Whereas, few large cooperative growers for export citrus production counties such as Shimen in Hunan and Pinghe in Fujian practiced AWCP to manage B. minax (Xia et al., 2018). Protein bait application along with proper sanitation effectively reduced infestation by fruit fly in papaya orchards in Hawaii (Jaime et al., 2009). A similar result was observed in the sweet orange orchards at Tinkanya village of Sindhuli district. NRs. 19,475,000 additional income was achieved from the investment of NRs. 3000,000 for the purchase of protein bait, technical and managerial support to the sweet orange (Junar) growers (Table 4).

\section{Conclusion}

Area-Wide Control Program of insect pest includes the tools in practices in the specific area at national, regional and smaller area levels. Fruit fly management measures such as lethal baiting (attracting and baiting fruit fly adults in the protein hydrolysate bait with insecticide), trapping, sanitation against pupating maggots, community awareness programs were employed in the specific location against CCF ( $B$. minax). The technical aspect and managerial functions are essential for the successful implementation of the AWCP of B. minax. At the same time, coordination among stakeholders is crucial to deploy AWCP. The cost of adaptation of AWCP economic and environmental friendly as it is applied in particular spots rather than blanket sprays of pesticides in conventional practices.

\section{Challenges}

Size of sweet orange orchards varied from small to bigger $\left(<500 \mathrm{~m}^{2}\right.$ to $\left.11500 \mathrm{~m}^{2}\right)$ included mostly small landholder growers. Besides, the orchards in scattered patterns with mountain terrain added difficult accessibility to pay a visit to growers (transportation problem. Mostly, the orchards were intercropped with maize that hindered smooth spray activity. Alternate hosts of CCF, B. minax has still not yet discovered in the Nepal context. Similarly, besides partial life history of $B$. minax, detail biology of this pest remained matters of study.

\section{Recommendations}

Along with the technical issues that support a successful AWCP of B. minax, attention should be given for the functional coordination among the concerned stakeholders with the addition of addressing a large number of non-technical issues that arise during the campaign. This is a novel technique should be transferred to the necessary problematic areas. Further research on biology and management of this insect pest should be continued.

\section{Acknowledgement}

Authors are thankful to the University Grants Commission, Bhaktapur and Agriculture and Forestry University, Chitwan, Nepal for providing support to conduct research activity on Chinese citrus fly. Equally, Sweet orange growers; Junar Superzone, Sindhuli; Karma Group, Kathmandu and Ecoman Biotech, China are acknowledged for conducting AWCP of fruit fly in Sindhuli, Nepal.

\section{Author's Contributions}

Debraj Adhikari: Coordinated in all research activities, data-analysis and write-up of the manuscript.

Resham Bahadur Thapa: Contributed in the research design, reviewed and advised for write-up. 
Samudra Lal Joshi: Contributed in the research design, data analysis reviewed and advised for overall write-up.

Xing Hui Liang: Contributed for the concept of area-wide control program of pest and reviewed on the write-up.

Jason Jinping Du: Contributed for the concept of area-wide control program of pest, supported on the research activities and reviewed on write-up.

\section{Ethics}

This article contains unpublished material and it is original research. The corresponding author confirms that all of the other authors have read and approved the manuscript and no ethical issues involved.

\section{References}

Adhikari, D. and D.B. Rayamajhi, 2012. Status of sweet orange production in Sindhuli district of Nepal. Nep. Hort., 9: 104-109.

Adhikari, D. and S.L. Joshi, 2018. An issue of sweet orange fruit fly in Sindhuli, Nepal: Possible management measures. Proceedings of the Chinese Citrus Fly (Bactrocera minax), (CCF' 18), Sindhuli, Nepal.

Adhikari, D., D.B. Tiwari and S.L. Joshi, 2018. Population dynamics of fruit flies in sweet orange (Citrus sinensis L.) orchards in Sindhuli, Nepal. J. Agric. Environ., 19: 9-18.

Adhikari, D., J. Dougoud, W. Janner and U. Schaffner, 2016. Assessment of performance of plant clinic in Nepal (a case of fruit fly management). MAS ICM Thesis, Université de Neuchâtel, Switzerland.

Aluja, M. and R.L. Mangan, 2008. Fruit fly (Diptera: Tephritidae) host status determination: Critical conceptual, methodological and regulatory considerations. Ann. Rev. Entomol., 53: 473-502. DOI: 10.1146/annurev.ento.53.103106.093350

Aluja, M., O. Mariano, L. Guillen and J. Rull, 2012. Understanding long-term fruit fly (Diptera: Tephritidae) population dynamics: Implications for area wide management. J. Econ. Entomol., 105: 823-36. DOI: 10.1603/EC11353

Amgai, R.B., H.K. Prasai and Y.R. Pandey, 2016. Hormonal effect on mandarin orange (Citrus reticulata Blanco) Micro-propagation. Nep. J. Biotechnol., 4: 33-36. DOI: 10.3126/njb.v4i1.16344

ASEAN SAS, 2015. Fruit-fly-management-leaflet- Acase-study-on-wide-area-management-in-Indonesia. Bactrocera flies: Major pests of fruit and vegetable crops. ASEAN Sustainable Agrifood System.

DADO Sindhuli, 2018. Area and production of sweet orange in Sindhuli, Nepal and damage of sweet orange fruits due to Chinese citrus fly (Bactrocera minax) in Sindhuli, Nepal. District Agriculture Development Office, Sindhuli, Nepal.
Jaime, C.P.E., F.L.M. Ronald and R.I. Vargas, 2009. Managing oriental fruit fly (Diptera: Tephritidae), with Spinosad-based protein bait sprays and sanitation in papaya orchards in Hawaii. J. Econ. Entomol., 102: 1123-1132.

DOI: $10.1603 / 029.102 .0334$

Jessup, A., B. Woods, C. Smallridge and A. Tomkins, 2005. Area-wide management of fruit flies in Australia. Proceedings of the FAO/IAEA International Conference on Area-Wide Control of Insect Pests: Integrating the Sterile Insect and Related Nuclear and Other Techniques, May 9-13, Vienna, Austria, pp: 31-32.

Jessup, A.J., B. Dominiak, B. Woods, C.P.F. De Lima and A. Tomkins et al., 2007. Area-Wide Management of Fruit Flies in Australia. In: AreaWide Control of Insect Pests, Vreysen, M.J.B., A.S. Robinson and J. Hendrichs (Eds.), Springer, Dordrecht, pp: 685-697.

Joshi, S.L., 2019. Bactrocera minax (Enderlein) (Diptera: Tephritidae) and its invasion in Nepal. Prime Minister Agriculture Modernisation Project, Project Implementation Unit. Khumaltar, Lalitpur. (Seminar presentation).

Kogan, M. and W.I. Bajwa, 1999. Integrated pest management: A global reality? Ann. Soc. Entomol. Brasil, 28: 1-25. DOI: $10.1590 / \mathrm{S} 0301-80591999000100001$

NRC, 2010. Strategic planning for the Florida citrus industry: Addressing citrus greening disease, The National Academies Press, Washington, DC.

Parmesan, C. and G. Yohe, 2003. A globally coherent fingerprint of climate change impacts across natural systems. Nature, 421: 37-42.

Stenseth, N.C., A. Mysterud, G. Ottersen, J.W. Wurrell and K.S. Chan et al., 2002. Ecological effects of climate fluctuations. Science, 297: 1292-1296.

USDA, 2009. Final report- animal and plant health inspection service United States and Mexico lower Rio Grande valley Mexican fruit fly eradication program review.

Vargas, R.I., R.L. Mau and E.B. Jang, 2007. The Hawaii fruit fly area-wide pest management program: Accomplishments and future directions. Proc. Hawaiian Entomol. Soc., 39: 99-104.

Xia, Y., X.L. Ma, B.H. Hou and G.C. Ouyang, 2018. A review of Bactrocera minax (Diptera: Tephritidae) in China for the purpose of safeguarding. Adv. Entomol., 6: 35-61. DOI: 10.4236/AE.2018.62005 